\title{
Synthesis, crystal structure and Thermogravimetry of ortho-phthalic acid bridged coordination polymer of Copper(II)
}

\author{
BABITA SARMA, SAURAV BHARALI and DIGANTA KUMAR DAS* \\ Department of Chemistry, Gauhati University, Guwahati 781 014, Assam, India \\ e-mail: digantakdas@gmail.com
}

MS received 21 April 2015; revised 31 March 2016; accepted 1 April 2016

\begin{abstract}
Coordination polymer of $\mathrm{Cu}(\mathrm{II})$ bridged by $o$-phthalic acid alone is not known. The reaction of $\mathrm{CuCl}_{2} \cdot 2 \mathrm{H}_{2} \mathrm{O}$ with (2-butoxycarbonyl)benzoic acid yielded three dimensional coordination polymer bridged by $o$-phthalic acid. X-ray crystal structure shows structure with monoclinic $P 2_{1} / c$ space group. $o$-Phthalic acid molecules act as bridge between two $\mathrm{Cu}$ (II), one carboxylate binds to one $\mathrm{Cu}(\mathrm{II})$ as bidentate while the other carboxylate binds to another $\mathrm{Cu}$ (II) as monodentate. The four planar co-ordination positions of $\mathrm{Cu}$ (II) are satisfied by two chelated carboxylates while fifth and sixth co-ordination positions are satisfied by monodentate carboxylates. EPR and TGA of the coordination polymer are also reported.
\end{abstract}

Keywords. $o$-Phthalic acid; coordination polymer; X-ray crystal structure; Copper(II); EPR; TGA.

\section{Introduction}

Coordination polymers have multifunctional properties with tremendous potential for applications in many fields like catalysis, ${ }^{1-3}$ separation, ${ }^{4}$ hydrogen storage,${ }^{5,6}$ magnetic devices, ${ }^{7}$ non-linear optics, ${ }^{8}$ etc. By selecting appropriate metal ions and organic linkers, coordination polymers of different structures such as $1 \mathrm{D}$ chains, ladders, 2D grids and 3D networks could be designed. ${ }^{9-13}$

Polycarboxylic acids have been widely used as linkers, as they can coordinate by a number of different modes, to synthesise coordination polymers of different structures. ${ }^{14,15} o$-Phthalic acid has been widely explored as linker in synthesising coordination polymers. ${ }^{16-33}$ This immense popularity of $o$-phthalic acid as linker in coordination polymers is because of its ability to provide 26 different modes of coordination. ${ }^{34}$ In all these reported coordination polymers, at least one other ligand is found to be present together with $o$-phthalic acid. $o$-phthalic acid in the absence of other ligands resulted in monomeric complexes when allowed to react directly with $\mathrm{Cu}$ (II) ion at room temperature. ${ }^{35}$ There is no report of coordination polymer based on $o$-phthalic acid alone without incorporating other ligands.

We report herein for the first time, room temperature synthesis of three dimensional coordination polymer of $\mathrm{Cu}$ (II) with $o$-phthalic acid without incorporating any other ligand. To prevent formation of mononuclear complex, $o$-phthalic acid was not provided directly but generated in situ from (2-butoxycarbonyl)benzoic acid.

\footnotetext{
*For correspondence
}

\section{Experimental}

\subsection{Materials and methods}

All the chemicals and solvents were purchased from Merck. The organic solvents were distilled $\mathrm{CuCl}_{2} \cdot 2 \mathrm{H}_{2} \mathrm{O}$ was recrystallised from double distilled water before use. FTIR and UV-Visible spectra were recorded on Perkin Elmer RX1 FT-IR spectrophotometer and Shimadzu UV-1800 (with a $1.0 \mathrm{~cm}$ path length quartz cell) spectrophotometer, respectively. ${ }^{1} \mathrm{H}$ NMR spectra were recorded in Bruker ULTRASHILD $300 \mathrm{MHz}$ instrument. The EPR spectra were recorded in JEOL JESFA200. Electrochemical analysis was performed in CHI 600B Electrochemical Analyzer (USA) comprising of three electrode cell assembly. Platinum disc was used as working electrode, $\mathrm{Ag}-\mathrm{AgCl}(3 \mathrm{M} \mathrm{NaCl})$ as reference while a platinum wire as the counter electrode. The electrodes were cleaned as per reported procedure. ${ }^{36}$

Single crystal X-ray diffraction data were recorded employing Bruker Smart APEX II (3 circle X-ray diffractometer). The intensity data for the complex were collected using Mo-K $\alpha$ radiation $(0.71073 \AA$ ) at $293 \mathrm{~K}$ on a Bruker SMART APEX and Bruker KAPPA APEX II diffractometers, respectively. The SMART ${ }^{37}$ program was used for collecting frames of data, indexing the reflections, and determination of lattice parameters; SAINT ${ }^{38}$ program for integration of the intensity of reflections and scaling; SADABS ${ }^{39}$ program for empirical absorption corrections. The structures were solved by direct methods (SHELXS-97) and standard Fourier techniques, and refined on $F^{2}$ using full matrix least 
squares procedures (SHELXL-97) using the SHELX-97 package ${ }^{40}$ incorporated in Win GX. ${ }^{41}$ All non-hydrogen atoms were refined anisotropically except for the two lattice water molecules which are in a highly disordered state. Hydrogen atoms were assigned idealized positions and given thermal parameters equivalent to either 1.5 (methyl hydrogen atoms) or 1.2 (all other hydrogen atoms) times the thermal parameter of the carbon atoms to which they are attached. Hydrogen atoms of the lattice water molecules were not found.

\subsection{Synthesis of (2-butoxycarbonyl)benzoic acid $(L)$}

$1.48 \mathrm{~g}(10 \mathrm{mmol})$ phthalic anhydride and $0.91 \mathrm{~mL}$ $(10 \mathrm{mmol})$ of 1-butanol were taken in $20 \mathrm{~mL}$ methanol and stirred at $60^{\circ} \mathrm{C}$ for $10 \mathrm{~min} ; 2-3$ drops of pyridine were added and stirring continued for another $2 \mathrm{~h}$. An off-white product was obtained which was recrystallised from methanol. Yield: $0.304 \mathrm{~g}$ (85\%); M.p. $178^{\circ} \mathrm{C}$. FTIR $\left(\mathrm{KBr}, \mathrm{cm}^{1}\right): 3475\left(v_{\mathrm{O}-\mathrm{H}}\right), 2962\left(v_{\mathrm{C}-\mathrm{H}}\right)$, $1725\left(v_{\mathrm{C}=\mathrm{O}}\right), 1417\left(v_{\mathrm{C}=\mathrm{C}}\right), 1125$ and $1293\left(v_{\mathrm{C}-\mathrm{O}}\right) .{ }^{1} \mathrm{H}$ NMR $\left(\mathrm{CDCl}_{3}, 300 \mathrm{MHz}, \delta\right.$ in ppm, TMS $): 7.99-7.47$ $(\mathrm{m}, 4 \mathrm{H}), 4.17(\mathrm{~m}, 2 \mathrm{H}), 1.67-1.58(\mathrm{~m}, 2 \mathrm{H}), 1.42-1.30(\mathrm{~m}$, $2 \mathrm{H}), 7.2(\mathrm{t}, 3 \mathrm{H})$. Anal.Calcd. for $\mathrm{C}_{12} \mathrm{H}_{14} \mathrm{O}_{4}$ : C 64.86\%; H $6.35 \%$. Found: C $64.76 \%$; H $6.48 \%$.

The synthetic strategy for the preparation of the ligand $(\mathbf{L})$ is summarized in scheme 1 below:

\subsection{Synthesis of \\ $\left[\left\{\mathrm{Cu}\left(\mathrm{O}_{2} \mathrm{C}-\mu_{2}-\mathrm{C}_{6} \mathrm{H}_{5}-\mu_{1}-\mathrm{CO}_{2}\right)_{2}\right\} \cdot 2 \mathrm{H}_{2} \mathrm{O}\right]_{n}$}

$\mathrm{CuCl}_{2} .2 \mathrm{H}_{2} \mathrm{O}(0.170 \mathrm{~g}, 1 \mathrm{mmol})$ and $\mathbf{L}(0.358 \mathrm{~g}, 1 \mathrm{mmol})$ were stirred in $20 \mathrm{~mL} \mathrm{CH}_{3} \mathrm{OH}$ at room temperature for $2 \mathrm{~h}$. Blue crystals were precipitated out from the reaction mixture on standing for seven days. Recrystallisation was done from 1:10 (v/v) mixture of $\mathrm{CH}_{3} \mathrm{OH}: \mathrm{H}_{2} \mathrm{O}$. Yield: $70 \%$. MW 429.72.

\section{Results and Discussion}

\subsection{FTIR spectrum of $\left[\left\{\mathrm{Cu}\left(\mathrm{O}_{2} \mathrm{C}-\mu_{2}-\mathrm{C}_{6} \mathrm{H}_{5}-\mu_{1}-\mathrm{CO}_{2}\right)_{2}\right\} \cdot 2 \mathrm{H}_{2} \mathrm{O}\right]_{n}$}

The FT-IR spectrum of the complex showed characteristic peaks due to the ligation of carboxylate.
The peaks appearing in the region $1595-1611 \mathrm{~cm}^{-1}$ can be attributed to $v_{\text {asym }}(\mathrm{COO})$ vibrations while the peaks in the range $1382-1396 \mathrm{~cm}^{-1}$ can be attributed to $v_{\text {sym }}(\mathrm{COO})$ vibrations.

\subsection{EPR spectrum of \\ $\left[\left\{\mathrm{Cu}\left(\mathrm{O}_{2} \mathrm{C}-\mu_{2}-\mathrm{C}_{6} \mathrm{H}_{5}-\mu_{1}-\mathrm{CO}_{2}\right)_{2}\right\} \cdot 2 \mathrm{H}_{2} \mathrm{O}\right]_{n}$}

The EPR spectrum of the complex was recorded as polycrystalline solid and has been shown in figure 1 . The $\mathrm{g}_{\text {iso }}$ value and geometric parameter $\mathrm{G}$, i.e., the measurement of exchange interaction between the copper centers were evaluated by using the following expression. ${ }^{42,43}$

$$
\begin{gathered}
g_{\text {iso }}=\left(g_{\|}+2 g_{\perp}\right) / 3 \\
\mathrm{G}=\left(\mathrm{g}_{\|}-2.0023\right) /\left(\mathrm{g}_{\perp}-2.0023\right)
\end{gathered}
$$

The calculated value of $\mathrm{g}$ tensor parameter were $\mathrm{g}_{11}=$ 2.63 and $g_{\perp}=2.47$. Hence $g_{11}>g_{\perp}>2.0023$ which reveals that $\mathrm{d}_{\mathrm{x} 2-\mathrm{y} 2}$ is the ground state. ${ }^{44}$ The value of $\mathrm{G}$ was calculated to be 1.34 which is less than 4 indicating effective interaction between the copper centers. ${ }^{45}$

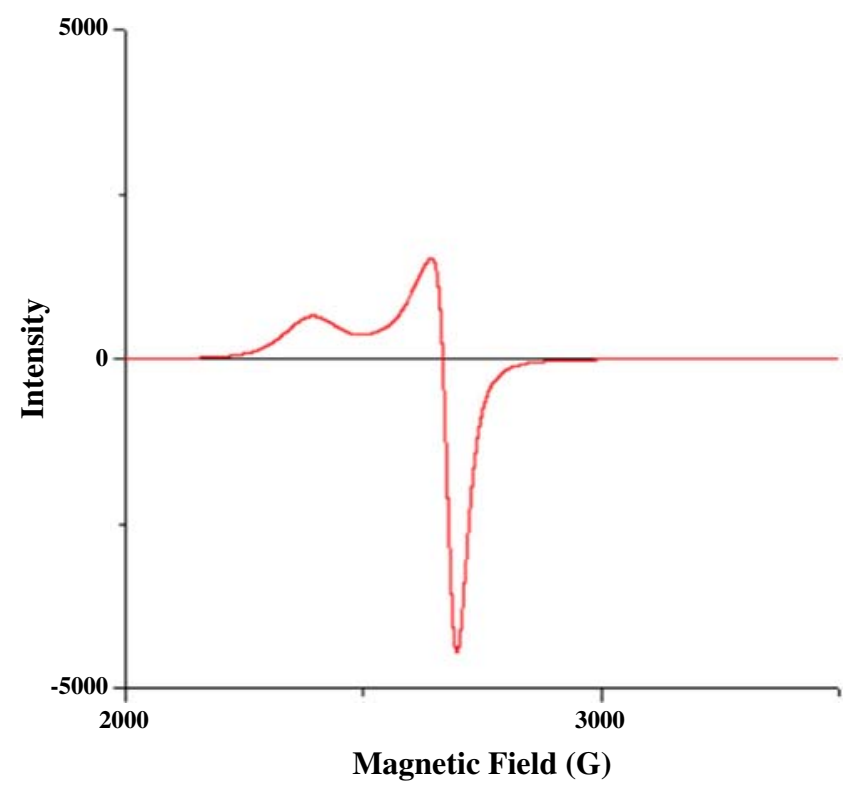

Figure 1. EPR spectrum of the coordination polymer in polycrystalline state.

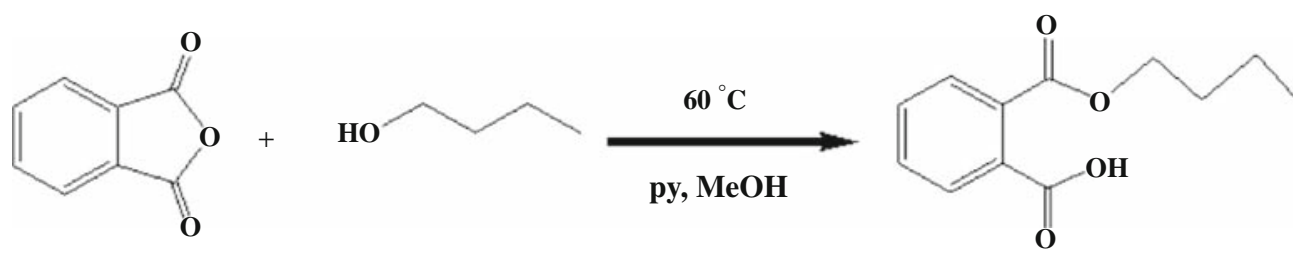

(L)

Scheme 1. Synthetic path for $\mathbf{L}$. 


\subsection{Thermogravimetric analysis (TGA) of $\left[\left\{\mathrm{Cu}\left(\mathrm{O}_{2} \mathrm{C}-\mu_{2}-\mathrm{C}_{6} \mathrm{H}_{5}-\mu_{1}-\mathrm{CO}_{2}\right)_{2}\right\} .2 \mathrm{H}_{2} \mathrm{O}\right]_{n}$}

Figure 2 shows the TGA curve of the coordination polymer. The weight loss was obseved from $180^{\circ} \mathrm{C}$ to $400^{\circ} \mathrm{C}$. The first weight loss is a well-defined step with initiation temperature $180^{\circ} \mathrm{C}$ due to loss of guest water molecules while the second and the third weight losses are combined ones with initiation temperatures ca. $270^{\circ} \mathrm{C}$ and $340^{\circ} \mathrm{C}$, respectively. The total weight loss in the three step process is $81.95 \%$ which accounts for the loss of phthalic acids from one monomeric unit

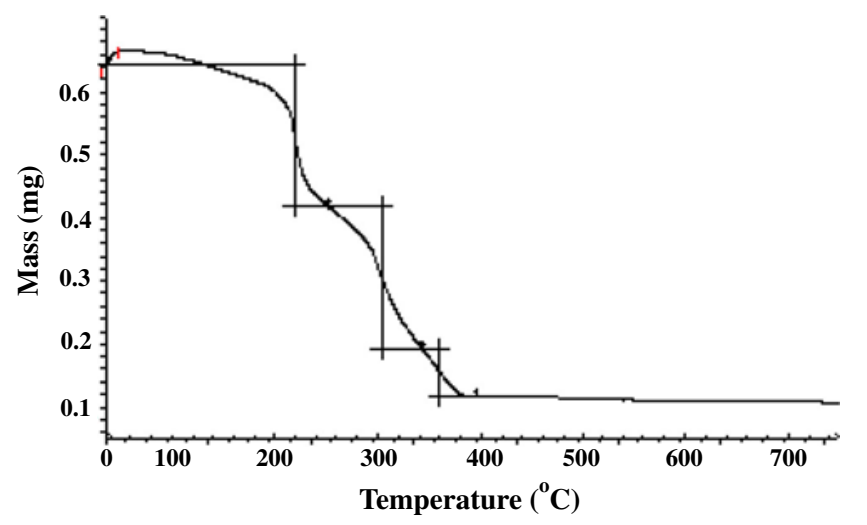

Figure 2. TGA curve of the coordination polymer. of the coordination polymer and formation of $\mathrm{CuO}$ as the final residue (calculated value of weight loss is $81.49 \%)$.

\subsection{Magnetic moment measurement of $\left[\left\{\mathrm{Cu}\left(\mathrm{O}_{2} \mathrm{C}-\mu_{2}-\mathrm{C}_{6} \mathrm{H}_{5}-\mu_{1}-\mathrm{CO}_{2}\right)_{2}\right\} \cdot 2 \mathrm{H}_{2} \mathrm{O}\right]_{n}$}

To investigate the spin state of $\mathrm{Cu}^{2+}$ in the complex, the magnetic susceptibility measurement was done at $298 \mathrm{~K}$ from mass susceptibility measurement. The mass susceptibility, $\chi_{\mathrm{g}}$, is calculated using the equation:

$$
\chi_{\mathrm{g}}=\left[C_{\text {Bal }} \times l \times\left(\mathrm{R}-\mathrm{R}_{\mathrm{o}}\right)\right] / 109 \times \mathrm{m}
$$

Where $l=$ the sample length $(\mathrm{cm}), \mathrm{m}=$ the sample mass $(\mathrm{g}), \mathrm{R}=$ the reading for the tube plus sample, $\mathrm{R}_{0}=$ the empty tube reading, $\mathrm{C}_{\mathrm{Bal}}=$ the balance calibration constant. Then molar susceptibility, $\chi_{\mathrm{m}}=\chi_{\mathrm{g}} \times$ molecular mass of the complex. The effective magnetic moment, $\mu_{\mathrm{eff}}$, is then calculated using the expression: $\mu_{\text {eff }}=2.83 \sqrt{ }\left(\chi_{\mathrm{m}} \times 298\right)$. The experimental value of magnetic moment was calculated to be $1.78 \mathrm{BM}$ which is almost equal to the spin only magnetic moment value due to $\mathrm{Cu}^{2+}$ ion, which is $1.732 \mathrm{BM}$. Hence, the $\mathrm{Cu}$ (II) ions in the co-ordination polymer are magnetically independent and should be well separated.

Table 1. Crystal data and structure refinement for $\left[\left\{\mathrm{Cu}\left(\mathrm{O}_{2} \mathrm{C}-\mu_{2}-\mathrm{C}_{6} \mathrm{H}_{5}-\mu_{1}-\mathrm{CO}_{2}\right)_{2}\right\} \cdot 2 \mathrm{H}_{2} \mathrm{O}\right]_{n}$.

CCDC Number 903426

Empirical formula

Formula weight

Temperature

Wavelength

Crystal system, space group

Unit cell dimensions

Volume

$Z$, Calculated density

Absorption coefficient

$\mathrm{F}(000)$

Crystal size

Theta range for data collection

Limiting indices

Reflections collected / unique

Completeness to theta $=27.49$

Refinement method

Data / restraints / parameters

Goodness-of-fit on $\mathrm{F}^{2}$

Final $\mathrm{R}$ indices $[\mathrm{I}>2 \operatorname{sigma}(\mathrm{I})]$

$\mathrm{R}$ indices (all data)

Extinction coefficient

Shift/esd max

Largest diff. peak and hole
: $\mathrm{C}_{16} \mathrm{H}_{10} \mathrm{Cu} \mathrm{O} \mathrm{O}_{8} .2 \mathrm{H}_{2} \mathrm{O}$

:489.79

:296(2) K

:0.71073 $\AA$

:Monoclinic, $P 2_{1} / c$

$: a=11.0782(11) \AA$ alpha $=90 \mathrm{deg}$.

$\mathrm{b}=6.6521(7) \AA$ beta $=101.798(4) \mathrm{deg}$.

$\mathrm{c}=12.1645(12) \AA$ gamma $=90 \mathrm{deg}$.

:877.50(15) $\AA^{3}$

$: 2,1.854 \mathrm{Mg} / \mathrm{m}^{3}$

$: 1.328 \mathrm{~mm}^{-1}$

:494.0

$: 0.38 \times 0.32 \times 0.24 \mathrm{~mm}$

:3.42 to $27.49 \mathrm{deg}$.

$:-14<=\mathrm{h}<=14,-7<=\mathrm{k}<=8,-15<=1<=15$

:8917 / 2004 [R(int) $=0.0275]$

$: 94.7 \%$

Full-matrix least-squares on $\mathrm{F}^{2}$

: 1899 / 0 / 147

$: 1.065$

$: \mathrm{R} 1=0.0545, \mathrm{wR} 2=0.1878$

$: \mathrm{R} 1=0.0634, \mathrm{wR} 2=0.2144$

$: 0.023(6)$

:0.000

$: 0.901$ and -1.389 e. $\mathrm{A}^{-3}$

$w R_{2}=\left\{\Sigma\left[w\left(F_{\mathrm{o}}^{2}-F_{\mathrm{c}}^{2}\right)^{2}\right] / \Sigma\left[w\left(F_{\mathrm{o}}^{2}\right)^{2}\right]\right\}^{1 / 2}$ where $w=1 /\left[\sigma^{2}\left(F_{o}^{2}\right)+(a P)^{2}+b P\right]$ with $P$ is $\left[2 F_{c}^{2}+\right.$ $\left.\operatorname{Max}\left(F_{o}^{2}, 0\right)\right] / 3$ 


\subsection{X-ray crystallography of \\ $\left[\left\{\mathrm{Cu}\left(\mathrm{O}_{2} \mathrm{C}-\mu_{2}-\mathrm{C}_{6} \mathrm{H}_{5}-\mu_{1}-\mathrm{CO}_{2}\right)_{2}\right\} .2 \mathrm{H}_{2} \mathrm{O}\right]_{n}$}

Discrete single dark blue crystals of the compound suitable for X-ray studies were obtained from the concentrated reaction mixture by allowing the resulting solution to stand for seven days at room temperature. Recrystallization of the complex was done from 1:10 (v/v) mixture of $\mathrm{CH}_{3} \mathrm{OH}: \mathrm{H}_{2} \mathrm{O}$. The complex crystallizes in the monoclinic crystal system with $P 2_{1} / c$ space group. The crystallographic data has been shown in table 1. Selected bond lengths $[\AA ̊]$ and bond angles [deg.] for the compound have been shown in tables 1 and 2 .

The unit cell structure of the complex is shown in figure 3 . The structure shows that the butoxy group from the ligand is lost during the formation of the complex and phthalic acid acts as a bridging ligand in the complex. Each $\mathrm{Cu}$ (II) ion is coordinated with four phthalate ligands completing an octahedral structure with six $\mathrm{O}$ atoms. Out of the four phthalate two coordinates to the $\mathrm{Cu}$ (II) through both $\mathrm{O}$ atoms of one carboxylate as chelate. These two chelating carboxylates are found to be in trans position to each other. Each of the

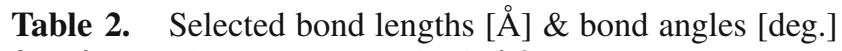
for $\left[\left\{\mathrm{Cu}\left(\mathrm{O}_{2} \mathrm{C}-\mu_{2}-\mathrm{C}_{6} \mathrm{H}_{5}-\mu_{1}-\mathrm{CO}_{2}\right)_{2}\right\} .2 \mathrm{H}_{2} \mathrm{O}\right]_{n}$.

$\begin{array}{lc}\mathrm{Cu}(1)-\mathrm{O}(3) & 1.943(10) \\ \mathrm{Cu}(1)-\mathrm{O}(4) & 1.973(11) \\ \mathrm{O}(3)-\mathrm{Cu}(1)-\mathrm{O}(4) & 91.0(5)\end{array}$

Symmetry transformations used to generate equivalent atoms

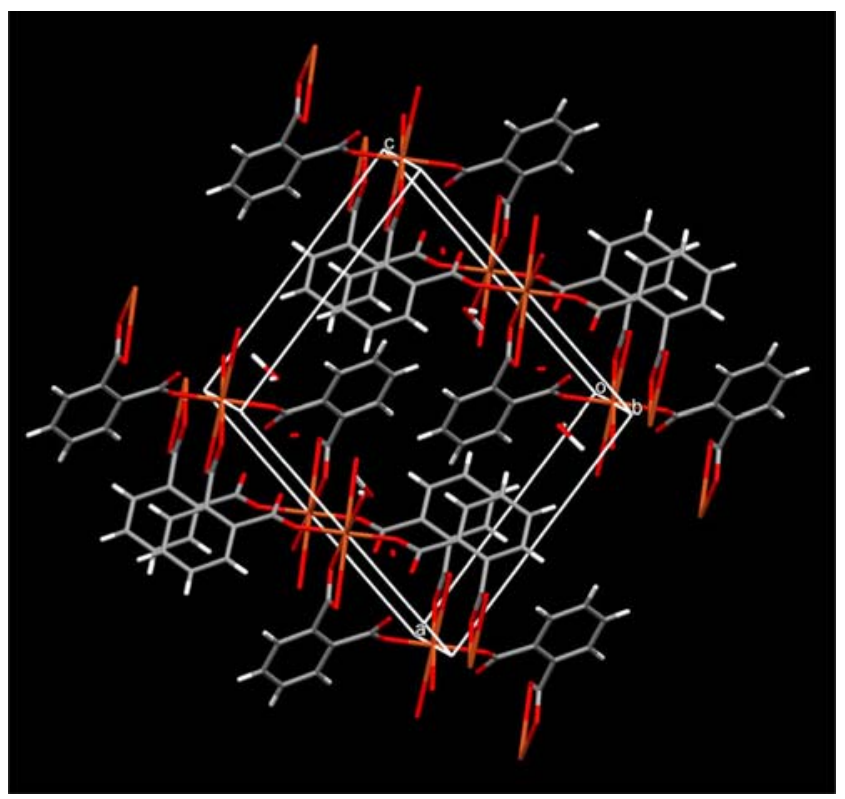

Figure 3. Packing of $\mathrm{Cu}$ complex showing the coordination environment around $\mathrm{Cu}$ along (101) plane. other carboxylates (of these two phthalates) binds to another $\mathrm{Cu}$ (II) through only one $\mathrm{O}$ atom while the other $\mathrm{O}$ dangles as keto group. The other two trans coordination sites of the $\mathrm{Cu}$ (II) are fulfilled by carboxylate $\mathrm{O}$ atoms of phthalate of which the remaining carboxylates chelate to two $\mathrm{Cu}$ (II). In this way, a three dimensional network is generated where each phthalate acts as a bridge between two $\mathrm{Cu}(\mathrm{II})$, and coordinating to one $\mathrm{Cu}$ (II) by the monodentate carboxylate oxygen and to another $\mathrm{Cu}$ (II) by chelating carboxylate.

In the compound the two trans $\mathrm{O}-\mathrm{Cu}(\mathrm{II})-\mathrm{O}$ angles created each by the two $\mathrm{O}$ atoms of a chelating carboxylate and the $\mathrm{Cu}$ (II) ion were found to be equal which is $53.19^{\circ}$. The other two $\mathrm{O}-\mathrm{Cu}(\mathrm{II})-\mathrm{O}$ angles were of value $126.81^{\circ}$. Interestingly the axial $\mathrm{Cu}(\mathrm{II})-\mathrm{O}$ bonds were not perfectly perpendicular to the plane of four equatorial $\mathrm{O}$ atoms from two chelating carboxylates. Each of the axial $\mathrm{Cu}(\mathrm{II})-\mathrm{O}$ bonds were found to be tilted slightly towards one of the two equatorial chelating carboxylate pairs. The $\mathrm{O}-\mathrm{Cu}(\mathrm{II})-\mathrm{O}$ angles involving one axial $\mathrm{O}$ atom and the $\mathrm{O}$ atoms from one pair of chelating carboxylate are $92.67^{\circ}$ and $90.99^{\circ}$ while these angles with the other pair of carboxylate are $89.01^{\circ}$ and $92.67^{\circ}$.

The distance between the two $\mathrm{Cu}$ (II) bound $\mathrm{O}$ atoms belonging to the same carboxylate is $2.216 \AA$ while the distance between the two $\mathrm{O}$ atoms (on the same side of the coordination core) belonging to two different carboxylates is $4.22 \AA$. Hence, the equatorial $\mathrm{O}_{4}$ core around the $\mathrm{Cu}$ (II) ion in the complex is rhombohedral. The asymmetric unit of the complex is shown in figure 4.

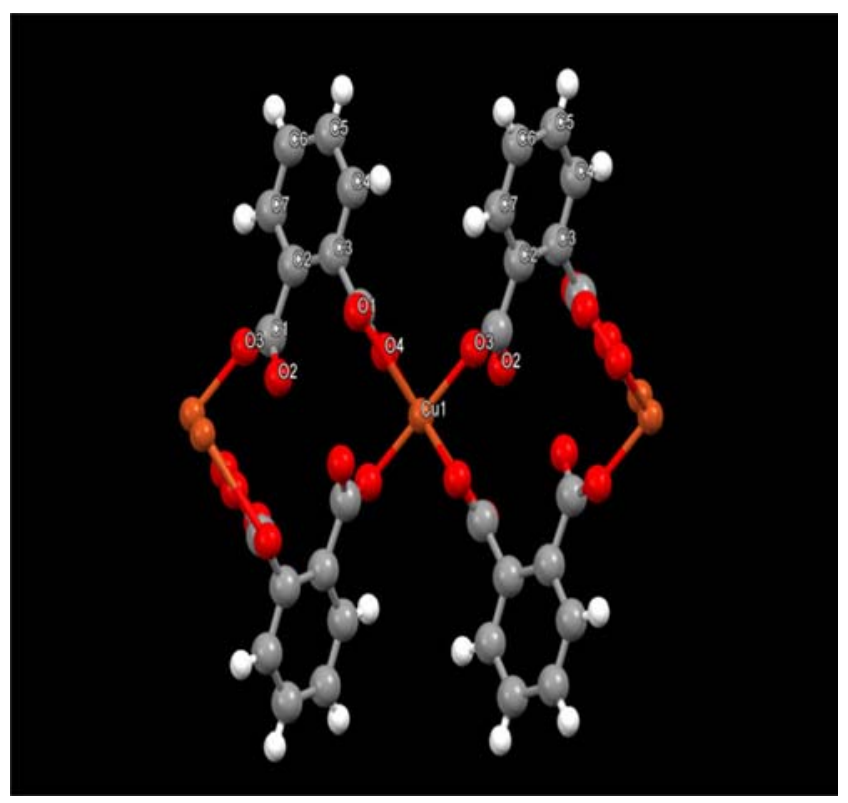

Figure 4. Phthalic acid coordinating with $\mathrm{Cu} 1$ through carboxylate oxygen in monodentate fashion. 
The coordination of two carboxylic groups of a phthalate to two different $\mathrm{Cu}$ (II) finally gives rise to a polymeric structure. Figure 5 shows the two dimensional structure of the polymeric system. In the three dimensional structure shown in figure 6 specific holes are clearly visualised. It also shows van der Waals interaction $(\pi-\pi)$ between the phthalate aromatic rings. The crystal packing arrangement of the compound is stabilized by the intermolecular $\mathrm{O}-\mathrm{H} \cdots \mathrm{O}$ interactions $(\sim 2.158 \AA)$ between solvent water hydrogen and carboxylate $\mathrm{O}$ atom.

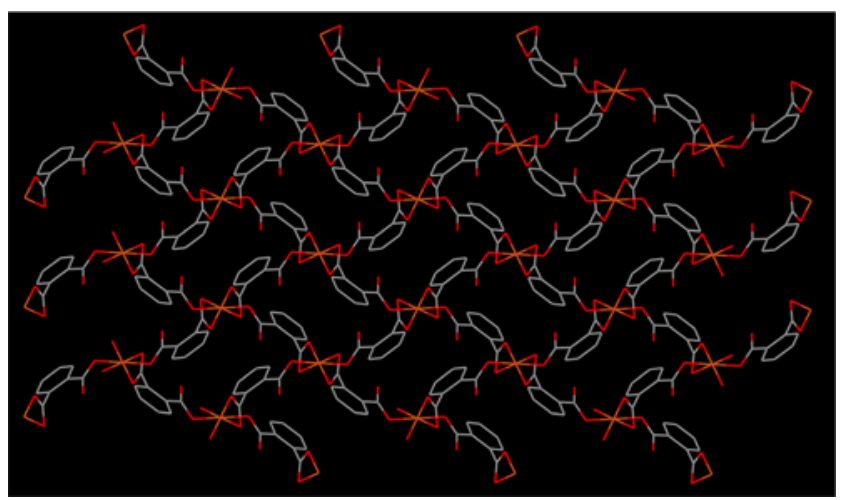

Figure 5. Two dimensional structure of the polymeric $\mathrm{Cu}(\mathrm{II})$ complex.

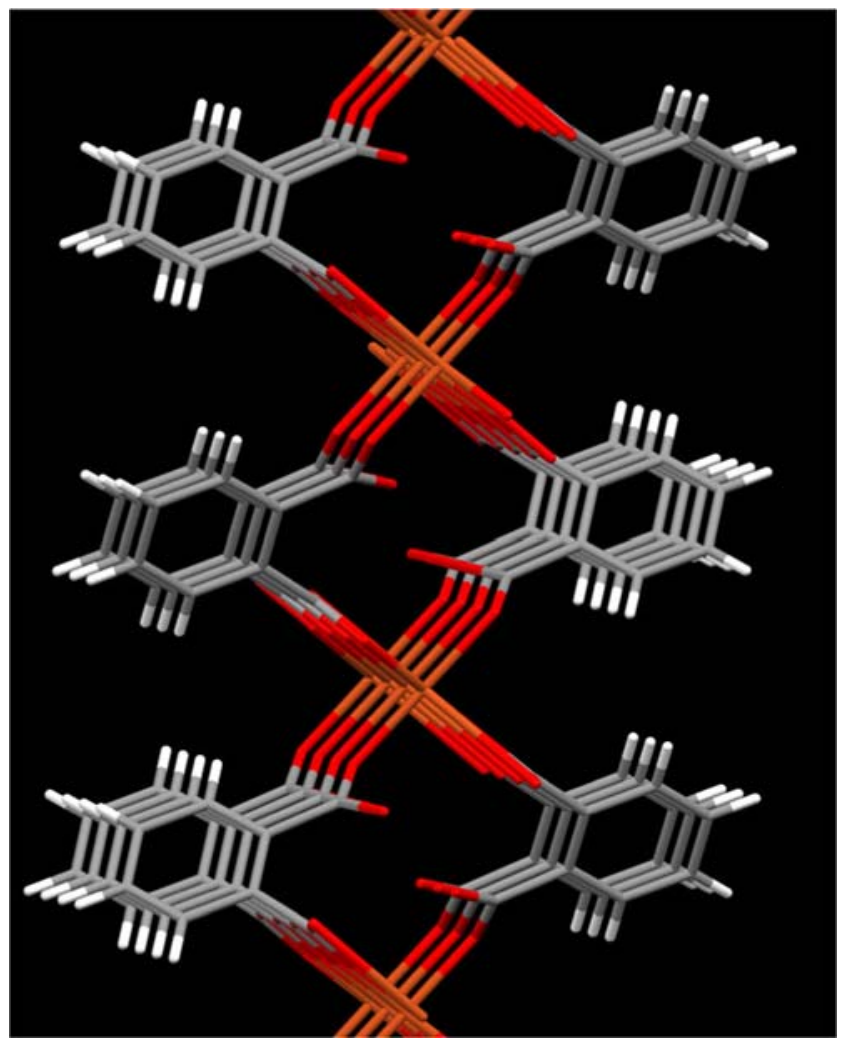

Figure 6. Three dimensional polymeric structure of the $\mathrm{Cu}(\mathrm{II})$ complex.



Figure 7. Observed (above) and calculated (below) powder X-ray diffraction of $\left\{-\mathrm{Cu}\left(\mu_{2}-\mathrm{O}_{2} \mathrm{C}-\mathrm{C}_{6} \mathrm{H}_{5}-\mathrm{CO}_{2}-\mu_{1}-\right)_{2}-\right\}$. $2 \mathrm{H}_{2} \mathrm{O}$.

\subsection{Powder X-ray diffraction study}

To prove the bulk purity of the complex synthesized by us, powder X-ray diffraction data was also collected for the complex. A close similarity observed between observed and calculated X-ray diffraction patterns prove the bulk purity of the complex (figure 7).

\section{Conclusions}

A novel three dimensional co-ordination polymer of $\mathrm{Cu}$ (II) with $o$-phthalic acid was obtained on reaction of $\mathrm{CuCl}_{2}$ and 4-(2-butoxycarbonyl)benzoic acid. X-ray crystallographic studies have shown a 3D coordination polymer with specific holes. TGA curve showed three weight losses with final composition as $\mathrm{CuO}$.

\section{Supplementary Information (SI)}

All additional information pertaining to characterization of the cocrystals, namely, FT-IR spectrum (figure S1), ${ }^{1} \mathrm{H}$ NMR spectrum (figure S2) and CIF (pdf file) are available at www.ias.ac.in/chemsci.

\section{Acknowledgements}

DST, New Delhi and UGC, New Delhi are thanked for FIST and SAP to the Department, respectively. B.S. thanks UGC for fellowship under RFSMS. SAIF, G.U. and CIF, IIT Guwahati are thanked for X-ray crystallographic data and EPR spectrum, respectively. 


\section{References}

1. Horike S, Dinca M, Tamaki K and Long J R 2008 J. Am. Chem. Soc. 1305854

2. Bhattacharya B, Maity D K, Pachfule P, Colacio E and Ghoshal D 2014 Inorg. Chem. Front. 1414

3. Yaghi O M, Okeeffe M, Ockwing N W, Chae H K, Eddaoudi M and Kim J 2003 Nature 423705

4. Couck S, Denayer J F M, Baron G V, Remy T, Gascon J and Kapteijn F 2009 J. Am. Chem. Soc. 1316326

5. Rosi N L, Eckert J, Eddaoudi M, Vodak D T, Kim J, Okeeffe M and Yaghi O M 2003 Science 3001127

6. Rowsell J L C, Millward A R, Park K S and Yaghi O M 2004 J. Am. Chem. Soc. 1265666

7. Dey R, Bhattacharya B, Colacio E and Ghoshal D 2013 Dalton Trans. 422094

8. Evans O R and Lin W B 2002 Acc. Chem. Res. 35 511

9. Shin D M, Lee I S, Lee Y A and Chung Y K 2003 Inorg. Chem. 422977

10. Bronisz R 2004 Inorg. Chim. Acta 357396

11. Ma Y, He Y K, Zhang L T, Gao J Q and Han Z B 2008 J. Chem. Crystallogr. 38267

12. Shin D M, Lee I S, Chung Y K and Lah M S 2003 Inorg. Chem. 425459

13. Ma B Q, Sun H L and Gao S 2005 Inorg. Chem. 44837

14. (a) Deacon G B and Phillips R J 1980 Coord. Chem. Rev. 33 251; (b) Tranchemon-tagne D J, Mendoza-Cortés J L, O'Keeffe M and Yaghi O M 2009 Chem. Soc. Rev. 38 1257

15. Che T L, Gao Q C, Zhang W P, Nan Z X, Li H Z, Cai Y Q and Zhao J S 2009 Russ. J. Coord. Chem. 35 723

16. Baca S G, Reetz M T, Goddard R, Filippova I G, Simonov Y A, Gdaniec M and Gerbeleu N 2006 Polyhedron 251215

17. Baca S G, Simonov Yu A, Gerbeleu N V, Gdaniec M, Bourosh P N and Timco G A 2001 Polyhedron 20 831

18. Baca S G, Filippova I G, Gerbeleu N V, Simonov Yu A, Gdaniec M, Timco G A, Gherco O A and Malaestean Yu L 2003 Inorg. Chim. Acta 344109

19. Baca S G, Filippova I G, Gherco O A, Gdaniec M, Simonov Yu A, Gerbeleu N V, Franz P, Basler R and Decurtins S 2004 Inorg. Chim. Acta 3573419

20. Baca S G, Malinovskii S T, Franz P, Ambrus Ch, Stoeckli-Evans H, Gerbeleu N V and Decurtins S 2004 J. Solid State Chem. 1772841

21. Baca S G, Filippova I G, Ambrus Ch, Gdaniec M, Simonov Yu A, Gerbeleu N, Gherco O A and Decurtins S 2005 Eur. J. Inorg. Chem. 3118

22. Smith G, Reddy A N, Byriel K A and Kennard C H L 1995 J. Chem. Soc., Dalton Trans. 3565
23. Whitcomb D R and Rogers R D 1997 Inorg. Chim. Acta 256263

24. Escuer A, Vicente R, Mautner F A and Goher M A S 1997 Inorg. Chem. 361233

25. Bakalbassis E G, Paschalidis D G, Raptopoulou C P and Tangoulis V 1998 Inorg. Chem. 374735

26. Chen Z -N, Zhang H -X, Yu K -B, Kang B -S, Cai H, Su C -Y, Wang T -W and Lu Z -L 1998 Inorg. Chem. 37 4775

27. Lightfoot P and Snedden A 1999 J. Chem. Soc. Dalton Trans. 3549

28. Zhang $\mathrm{H}-\mathrm{X}$, Kang B -S, Xu A -W, Chen Z -N, Zhou Z -Y, Chan A S C, Yu K -B and Ren C 2001 J. Chem. Soc. Dalton Trans. 2559

29. Wang S, Hou Y, Wang E, Li Y, Xu L, Peng J, Liu S and Hu C 2003 New J. Chem. 271144

30. Ma C, Chen C, Liu Q, Liao D, Li L and Sun L 2003 New J. Chem. 27890

31. Raj S B, Muthianh P T, Bocelli G and Canton A 2003 Inorg. Chem. Commun. 6748

32. Liu X, Xie C, Wang X, Shen G and Shen D 2003 Inorg. Chem. Commun. 61433

33. Thirumurugan A and Natarajan S 2004 J. Chem. Soc., Dalton Trans. 2923

34. Baca S G, Filippova I G, Gherco O A, Gdaniec M, Simonov Y A, Gerbeleu N V, Franz P, Basler R and Decurtins S 2004 Inorg. Chim. Acta 3573419

35. Shimizu I, Tsuchiya R and Kyuno E 1967 Bull. Chem. Soc. Jpn. 401162

36. Rajbongshi J, Das D K and Mazumdar S 2010 Electrochim. Acta 554174

37. SMART \& SAINT Software Reference Manuals, version 5.01998 (Bruker AXS Inc.: Madison, WI)

38. Sheldrick G M 1999 SADABS, BrukerNonius Area Detector Scaling and Absorption Correction, version 2.05 (University of Göttingen: Göttingen, Germany)

39. SheldrickG M 1998 SHELX-97, Program for the Solution and Refinement of Crystal Structures (University of Göttingen: Göttingen, Germany)

40. Farrugia L J 2003 WinGX: An Integrated System of Windows Programs for the Solution, Refinement and Analysis for Single Crystal X-ray Diffraction Data, version 1.65.04 (Department of Chemistry, University of Glasgow: Glasgow)

41. Farrugia L J 1999 J. Appl. Crystallogr. 32837

42. Mishra L and Upadhyay K K 1994 Ind. J. Chem. Sect. A 33A 683

43. Chandra S, Jain D and Sharma A K 2009 Spectrochim. Acta, Part A 711712

44. Searl J W, Smith R C and Wayrad S J 1959 Proc. Phys. Soc. London 74491

45. Hathaway B J and Billing D E 1970 Coord. Chem. Rev. 5143 